

\section{RUANG A}

\begin{tabular}{|c|c|c|c|}
\hline No. & Nama & Judal & Instltusi \\
\hline A.1 & $\begin{array}{l}\text { Mochammad Rojil Ghufron, } \\
\text { Dimas Dwi Utomo, Wahyo } \\
\text { Imroni, Warju }\end{array}$ & $\begin{array}{l}\text { Pengarah Diesel Particulate Trap (DPT) } \\
\text { Berbahan Dasar Miremesh Stainless Steel } \\
\text { Terhadap Reduksi Tingkat Kebisingan (Noise } \\
\text { Leoel) Pada Isuru Phanter Tahun } 1997\end{array}$ & $\begin{array}{l}\text { Universitas Negeri } \\
\text { Surabaya }\end{array}$ \\
\hline A.2 & $\begin{array}{l}\text { Ika Yuni Rachmati, Putri } \\
\text { Lilia Rosa, Susianto }\end{array}$ & $\begin{array}{l}\text { Efek Temperatur Dan Sodium Hidrnksida Parla } \\
\text { Pemisahan Bitumen Dari Absuton } \\
\text { Menggunakan Media Air Panas }\end{array}$ & $\begin{array}{l}\text { Institut Teknologi Sepuluh } \\
\text { Nopember }\end{array}$ \\
\hline$A^{3}$ & $\begin{array}{l}\text { This Sari Gioria Wurarah, } \\
\text { Viviane Dewi, Lanny S }\end{array}$ & $\begin{array}{l}\text { Sintesis Nanosilika Dari Black Liguor Sekam } \\
\text { Padi Melalui Teknik Ramah Lingkungan }\end{array}$ & Universitas Surabaya \\
\hline A.4 & $\begin{array}{l}\text { Maja Pranata M, Riza } \\
\text { Alviany, Firman K, } \\
\text { A. Roesyadi }\end{array}$ & $\begin{array}{l}\text { Produksi Katalis } \gamma-\mathrm{Al}_{2} \mathrm{O} \text {, dengan Promotor } \mathrm{Cr} \text { - } \\
\mathrm{Co} \text { Menggunakan Metode Impregnasi }\end{array}$ & $\begin{array}{l}\text { Institut Teknologi Sepuluh } \\
\text { Nopember }\end{array}$ \\
\hline A.S & $\begin{array}{l}\text { Noor Amalia Chusna, } \\
\text { Maryonn }\end{array}$ & $\begin{array}{l}\text { Potensi Pemanfaatan Timbulan Gas Metana Di } \\
\text { TPA Bandengan Kabupaten Jepara Sebagai } \\
\text { Peluang Produksi Energi } \\
\end{array}$ & Universitas Diponegoro \\
\hline A.6 & $\begin{array}{l}\text { Nurullafina S, Azka Afiza, } \\
\text { Eldira Nindri Wena, } \\
\text { Susianto, Ali Altway }\end{array}$ & $\begin{array}{l}\text { Pirolisis Katalitik Asbuton Menjadi Bahan } \\
\text { Bakar Cair Dengan Katalis Zeolite }\end{array}$ & $\begin{array}{l}\text { Institut Teknologi Sepuluh } \\
\text { Nopember }\end{array}$ \\
\hline A.7 & $\begin{array}{l}\text { Destrian H, Putu Ayu W P, } \\
\text { Ignatius G, Firman K, } \\
\text { A. Roesyadi }\end{array}$ & $\begin{array}{l}\text { Produksi Biofuel Menggunakan Katalis Ni- } \\
\text { Fe/HSZM-5 Dari Minyak Kelapa }\end{array}$ & $\begin{array}{l}\text { Institut Teknologi Sepuluh } \\
\text { Nopember }\end{array}$ \\
\hline A. 8 & $\begin{array}{l}\text { Sri Redjedi, Jayati Purri } \\
\text { utami, Ninik Sugatri }\end{array}$ & $\begin{array}{l}\text { Produksi Mesopori Silika Dari Batuan Piropilit } \\
\text { Melalui Proses Pembentukan Natrium Silikat }\end{array}$ & $\begin{array}{l}\text { Universitas Pembangunan } \\
\text { Nasional "Veteran" Jawa } \\
\text { Timur }\end{array}$ \\
\hline A. 9 & $\begin{array}{l}\text { Kindriari N W, Evireza Putri } \\
\text { A, Moch Taufiq, Lucky } \\
\text { Indrati U. }\end{array}$ & $\begin{array}{l}\text { Pembuatan Biobriket Dari Campuran Batubara } \\
\text { Dan Arang Tempurung Kelapa Dengan } \\
\text { Perekat Lignin Kayu Meranti }\end{array}$ & $\begin{array}{l}\text { Universitas Pembangunan } \\
\text { Nasional "Veteran" Jawa } \\
\text { Timur }\end{array}$ \\
\hline A. 10 & $\begin{array}{l}\text { Renanto, Robbi Utomo, } \\
\text { Alghifari Rifliansyab, Rizal } \\
\text { Arifis }\end{array}$ & $\begin{array}{l}\text { Penggunaan Metoda Perancangan Pinch Pada } \\
\text { Berbagai Operasi Dalam Industri Kimia }\end{array}$ & $\begin{array}{l}\text { Institut Teknologi Sepuluh } \\
\text { Nopember }\end{array}$ \\
\hline
\end{tabular}




\section{RUANG B}

\begin{tabular}{|c|c|c|c|}
\hline B.1 & $\begin{array}{l}\text { Rizal Syamharis, Mulyadi, } \\
\text { Prantasi Harmi Tjahjanti }\end{array}$ & $\begin{array}{l}\text { Prediksi Retak Pada Model Rangka Sepeda } \\
\text { Roda Tiga Untuk Pasien Pasca Stroke Dengan } \\
\text { Konsep Tadpole }\end{array}$ & $\begin{array}{l}\text { Universitas } \\
\text { Muhammadiyah Sidoarjo }\end{array}$ \\
\hline B.2 & $\begin{array}{l}\text { Rizki Firmansyah Setya } \\
\text { Budi, Wiku Lulus Widodo }\end{array}$ & $\begin{array}{l}\text { Pengaruh Waktu Konstruksi Terhadap Biaya } \\
\text { Pokok Produksi Listrik Pusat Listrik Tenaga } \\
\text { Nuklir }\end{array}$ & $\begin{array}{l}\text { Pusat Kajian Sistem Energi } \\
\text { Nuklir - Badan Tenaga } \\
\text { Nuklir Nasional }\end{array}$ \\
\hline B. 3 & $\begin{array}{l}\text { Rahmat G S, Prantasi Harmi } \\
\text { Tjahjanti }\end{array}$ & $\begin{array}{l}\text { Analisis Perbandingan Shaft Pompa } \\
\text { Sentrifugal Tipe VCN } 150 \text { Dengan Tipe VCL } \\
140\end{array}$ & $\begin{array}{l}\text { Universitas } \\
\text { Muhammadiyah Sidoarjo }\end{array}$ \\
\hline B. 4 & $\begin{array}{l}\text { Octya Celline, Febrians } \\
\text { Intan, Jessy Liliani, Yuana E } \\
\text { Agustin }\end{array}$ & $\begin{array}{l}\text { Sintesis Dan Karakterisasi Komposit Selulosa } \\
\text { Bakteri Dengan Penambahan Kitosan Untuk } \\
\text { Aplikasi Medis }\end{array}$ & Universitas Surabaya \\
\hline B.5 & $\begin{array}{l}\text { Syamsul Arif, Prantasi } \\
\text { Harmi Tjahjanti }\end{array}$ & $\begin{array}{l}\text { Analisa Uji Impak, Tekan, dan audiensi pada } \\
\text { box speaker dengan komposisi } 75 \% \\
\text { LMTJ }+24 \% \text { Reesin Poliester }+1 \% \text { Katalis }\end{array}$ & $\begin{array}{l}\text { Universitas } \\
\text { Muhammadiyah Sidoarjo }\end{array}$ \\
\hline B. 6 & $\begin{array}{l}\text { Faldy Alfian, Prantasi Harmi } \\
\text { Tjabjanti }\end{array}$ & $\begin{array}{l}\text { Anslisa Uji Mekanik Pada Bax Speaker } \\
\text { Komposisi 60\% LMTJ+1\% Lem PVC+39\% } \\
\text { (50\% Kanji + 50\% Urea) }\end{array}$ & $\begin{array}{l}\text { Universitas } \\
\text { Muhammadiyah Sidoarjo }\end{array}$ \\
\hline B.7 & $\begin{array}{l}\text { Dwi Hery A, Sani, Anis Z } \\
\text { Sabichi, Maya M S }\end{array}$ & $\begin{array}{l}\text { Pembuatan Kalsium Silikat Dari Cangkang } \\
\text { Telur Dan Abu Bagasse }\end{array}$ & $\begin{array}{l}\text { Universitas Pembangunan } \\
\text { Nasional "Veteran" Jawa } \\
\text { Timur }\end{array}$ \\
\hline B.8 & Siswanto M, Nurul W T & $\begin{array}{l}\text { Aplikasi Vacum Evaporator Pada Pembuatan } \\
\text { Minuman Jahe Merah Instan Menggunakan } \\
\text { Kristalizer Putar }\end{array}$ & $\begin{array}{l}\text { Universitas Pembangunan } \\
\text { Nasional "Veteran" Jawa } \\
\text { Timur }\end{array}$ \\
\hline B. 9 & $\begin{array}{l}\text { Sony Agung Nugroho, } \\
\text { Prantasi Harmi Tjahjanti }\end{array}$ & $\begin{array}{l}\text { Rancang Bangun Lengaa Ayun Dan Transmisi } \\
\text { Tambahan Untuk Motor Disabilitas }\end{array}$ & $\begin{array}{l}\text { Universitas } \\
\text { Muhammadiyah Sidoarjo }\end{array}$ \\
\hline B.10 & $\begin{array}{l}\text { Srie Muljani, Nove Kartika } \\
\text { Erliyanti }\end{array}$ & $\begin{array}{l}\text { Adsorben dari Limbah Industri Keramik untuk } \\
\text { Penjemihan CPO }\end{array}$ & $\begin{array}{l}\text { Universitas Pembangunan } \\
\text { Nasional "Veteran" Jawa } \\
\text { Timur }\end{array}$ \\
\hline
\end{tabular}




\section{RUANG C}

\begin{tabular}{|c|c|c|c|}
\hline No. & Nama & Judul & Institusi \\
\hline C.I & $\begin{array}{l}\text { Supriati Khotijatul Qubro, } \\
\text { Mariyatul Kiftiyah, } \\
\text { Trilaksono }\end{array}$ & $\begin{array}{l}\text { Sintesis Selulosa Asetat Berbahan Dasar Pulp } \\
\text { Ampas Tebu Dengan Modifikasi Rasio } \\
\text { Komposisi Ampas Tebu Dengan Natrium } \\
\text { Hidroksida }\end{array}$ & Universitas Jember \\
\hline C.2 & Ida Ayu Oka Suwati S & $\begin{array}{l}\text { Analisis Kinerja Lingkungan Jalan Di Sekitar } \\
\text { Perusahaan Pengolah Dan Pemurnian Tembaga } \\
\text { Di Kecamatan Maluk, Kabupaten Sumbawa } \\
\text { Barat }\end{array}$ & Universitas Mataram \\
\hline C. 3 & $\begin{array}{l}\text { Albert G K, Andreas L, } \\
\text { Cynthia E, Hadiatni R P, } \\
\text { Lieke R }\end{array}$ & $\begin{array}{l}\text { Studi Termodinamika Pada Adsorpsi Direct } \\
\text { Red } 31 \text { Dengan Adsorben Modified Rice Husk }\end{array}$ & Universitas Surabaya \\
\hline C. 4 & Dwi Ima Hikmawati & $\begin{array}{l}\text { Preparasi Serbuk Guguran Daun Jati (Teciona } \\
\text { Grandis) Kering Dan Aplikasinya Sebagai } \\
\text { Adsorben Metilen Biru Dengan Sistem Batch } \\
\end{array}$ & Universitas Pgri Madiun \\
\hline C. 5 & $\begin{array}{l}\text { Bambang W, Hana R, Penny } \\
\text { P }\end{array}$ & $\begin{array}{l}\text { Minyak Atsiri Dari Daun Salam Dengan } \\
\text { Proses Penyulingan Uap Dan Air }\end{array}$ & $\begin{array}{l}\text { Universitas Pembangunan } \\
\text { Nasional "Veteran" Jawa } \\
\text { Timur }\end{array}$ \\
\hline C.6 & $\begin{array}{l}\text { Ketut Sumada, L Urip } \\
\text { Widodo }\end{array}$ & $\begin{array}{l}\text { Pupuk Cair Biosilika-Plus Berbahan Baku } \\
\text { Limbah Abu Bagasse }\end{array}$ & $\begin{array}{l}\text { Universitas Pembangunan } \\
\text { Nasional "Veteran" Jawa } \\
\text { Timus }\end{array}$ \\
\hline C. 7 & $\begin{array}{l}\text { Dinar Ismilla Putri, Indah } \\
\text { Nur Laila, Titi Susilowati }\end{array}$ & $\begin{array}{l}\text { Pengaruh Penambahan Kaporit Dan PAC } \\
\text { Terhadap Sifat Pisika Dan Kimia Air Sanitasi } \\
\text { Di PT Semen Indonesia (Persero) Tbk Tuban }\end{array}$ & $\begin{array}{l}\text { Universitas Pembangunan } \\
\text { Nasional "Veteran" Jawa } \\
\text { Timur }\end{array}$ \\
\hline C.8 & $\begin{array}{l}\text { Tuani L Simangunsong, } \\
\text { Yunus Fransiscus, Elieser } \\
\text { Tarigan, Fitri D Kartikasari }\end{array}$ & $\begin{array}{l}\text { Kajian Pengelolaan Sampah Fakultas Farmasi } \\
\text { Dalam Mendukung Program Green Campus } \\
\text { Universitas SURABAYA }\end{array}$ & Universitas Surabaya \\
\hline
\end{tabular}




\section{RUANG D}

\begin{tabular}{|c|c|c|c|}
\hline Na. & Name & Judul & Instltual \\
\hline D.1 & $\begin{array}{l}\text { M Rifai Aqil Y, Karrisa O R, } \\
\text { Gilang A S, Muhammad } \\
\text { Fikri K, Ali Altway, Siti } \\
\text { Nurkhamidah }\end{array}$ & $\begin{array}{l}\text { Pemodelan Dan Simulasi Stripping Gas } \\
\text { Karbondioksida }\left(\mathrm{CO}_{2}\right) \text { Dari } \\
\text { Methyldiethanolamine (MDEA) Berpromotor } \\
\text { Dalam Kolom Berpacking }\end{array}$ & $\begin{array}{l}\text { Institut Teknologi Sepuluh } \\
\text { Nopember }\end{array}$ \\
\hline D.2 & Embun Rachma Haqiqi & $\begin{array}{l}\text { Analisis FTIR (Fourier Transform Infra Red) } \\
\text { Limbah Cangkang Telur Ayam Dikombinasi } \\
\text { Biomassa Sckam Padi Setelah Adsorpsi } \\
\text { Larutan Zat Warna Metil Orange : Variasi } \\
\text { Ukuran Sekam Padi }\end{array}$ & Universitas PGRI Madiun \\
\hline D. 3 & $\begin{array}{l}\text { Erlinda Ningsih, Achmad C } \\
\text { Niam, Yustia Wulandari } \\
\text { Mirzayanti, Pipit Febrianita, } \\
\text { Wanvia Vangesti }\end{array}$ & $\begin{array}{l}\text { Konversi FFA Parla Pembuatan Biodiesel Dari } \\
\text { Minyak Biji Kapuk (Ceiba Pentandra) } \\
\text { Menggunakan Katslis Ca/Hydrotalcite }\end{array}$ & $\begin{array}{l}\text { Institut Teknologi Adhi } \\
\text { Tama Surabaya }\end{array}$ \\
\hline D. 4 & $\begin{array}{l}\text { Ufafa Anggarini, Rosa Dwi } \\
\text { Sasala Putri, Anni Rahmat }\end{array}$ & $\begin{array}{l}\text { Aktivasi Kimia Karbon Sabut Siwalan } \\
\text { (Borassus Flabellifer) Dengan Perbandingan } \\
\text { Aktivator KOH, NAOH Dan } \mathrm{H}_{3} \mathrm{PO}_{4}\end{array}$ & $\begin{array}{l}\text { Universitas Internasional } \\
\text { Semen Indonesia }\end{array}$ \\
\hline D.5 & Bambang Ismuyanto & Zeolit Alam Diaktivasi Senyawa Alkali & $\begin{array}{l}\text { Universitas Brawijaya } \\
\text { Malang }\end{array}$ \\
\hline D. 6 & $\begin{array}{l}\text { Yatim Lailun Ni'mah,Arlita } \\
\text { Sandya Stya W, Harmami }\end{array}$ & $\begin{array}{l}\text { Studi Konduktivitas Solid Polymer Electrolyte } \\
\text { (SPE) PEO (Poly Ethylene Oxide)-LiCLO4 } \\
\text { (Lithium Perchlorate) Dengan Fly Ash Dari } \\
\text { PT. Tjiwi Kimia Sidoarjo }\end{array}$ & $\begin{array}{l}\text { Institut Teknologi Sepuluh } \\
\text { Nopember }\end{array}$ \\
\hline D.7 & $\begin{array}{l}\text { Caecilia Pujiastuti, Yustina } \\
\text { Ngatilah, Ketut Sumada, } \\
\text { Dinar Ismilla, Indah Nurlaila }\end{array}$ & $\begin{array}{l}\text { Removal Impurities Ion Ca, Mg. K Dan } \mathrm{SO}_{4} \\
\text { Pada Larutan Garam Dengan Metode } \\
\text { Pertukaran Ion Dalam Rangka Peningkatan } \\
\text { Kualitas Produk Garam }\end{array}$ & $\begin{array}{l}\text { Univergitas Pembangunan } \\
\text { Nasional "Veteran" Jawa } \\
\text { Timur }\end{array}$ \\
\hline D. 8 & $\begin{array}{l}\text { Dinar Ismilla Putri, Indah } \\
\text { Nur Laila }\end{array}$ & $\begin{array}{l}\text { Peningkatan Kualitas Garam Rakyat Menjadi } \\
\text { Garam Industri Menggunakan Metode } \\
\text { Pertukaran Ion }\end{array}$ & $\begin{array}{l}\text { Universitas Pembangunan } \\
\text { Nasional "Veteran" Jawa } \\
\text { Timur }\end{array}$ \\
\hline D. 9 & $\begin{array}{l}\text { Retno Dewati, Suprihatin, } \\
\text { Ketut Sumada }\end{array}$ & $\begin{array}{l}\text { Pengaruh Tinggi Unggun Diam Pada Proses } \\
\text { Presipitasi Larutan Natrium Silika Dengan Gas } \\
\text { Karbon Dioksida }\end{array}$ & $\begin{array}{l}\text { Universitas Pembangunan } \\
\text { Nasional "Veteran" Jawa } \\
\text { Timur }\end{array}$ \\
\hline D. 10 & $\begin{array}{l}\text { Arlini Dyah Radityaningrum, } \\
\text { Maritha Nilam Kusuma }\end{array}$ & $\begin{array}{l}\text { Kinerja Tamaman Scirpus Pada Horisontal } \\
\text { Constructed } \\
\text { Wetland Dalam Menurunkan Tss, Bod, } \\
\text { Eschericia Coliform } \\
\text { Dari Lumpur Tinja }\end{array}$ & $\begin{array}{l}\text { Institut Teknologi Adhi } \\
\text { Tama } \\
\text { Surabaya }\end{array}$ \\
\hline D.11 & $\begin{array}{l}\text { Edi Mulyadi, Nurul Widji } \\
\text { Triana }\end{array}$ & Kristalisasi Gula Semut Berbasis Glukose & $\begin{array}{l}\text { Universitas Pembangunan } \\
\text { Nasional "Veteran" Jawa } \\
\text { Timur }\end{array}$ \\
\hline
\end{tabular}




\title{
PREPARASI SERBUK GUGURAN DAUN JATI KERING (Tectona grandis) DAN APLIKASINYA SEBAGAI ADSORBEN METILEN BIRU DENGAN SISTEM BATCH
}

\author{
Dwi Ima Hikmawati ${ }^{1}$ \\ Program Studi Teknik Kimia, Fakultas Teknik, Universitas PGRI Madiun ${ }^{1}$ \\ ${ }^{1)}$ Email: di.hikmawati@unipma.ac.id
}

\begin{abstract}
Abstrak
Pengembangan adsorben untuk mengatasi permasalahan lingkungan merupakan inovasi yang terus dilakukan oleh para peneliti. Dalam penelitian ini, guguran daun jati (Tectona grandis) kering berhasil disiapkan sebagai adsorben zat warna metilen biru dalam larutan air. Guguran daun jati disiapkan menjadi serbuk dan dicuci menggunakan air kran dan aquadest hingga menghasilkan filtrat tidak berwarna. Pengeringan serbuk daun jati yang telah dicuci dilakukan pada suhu $67{ }^{\circ} \mathrm{C}$ selama 12 jam. Sifat adsorpsi material dipelajari melalui sistem batch pada suhu dan $\mathrm{pH}$ ambient. Parameter operasional yang diberikan untuk mengevaluasi kinerja adsorben adalah variasi waktu kontak, rasio massa adsorben:volume larutan MB, dan konsentrasi metilen biru awal. Pengadukan pada proses adsorpsi menggunakan magnetic stirrer dengan kecepatan $800 \mathrm{rpm}$. Persentase adsorpsi MB memberikan hasil sebesar 98,56\% dengan rasio massa adsorben:volume larutan adalah $1 \mathrm{~g}: 35$ mL selama 30 menit waktu kontak. Hal ini menunjukkan bahwa guguran daun jati kering memiliki potensi yang bagus dan perlu untuk dikembangkan sebagai adsorben yang mudah dan efektif.
\end{abstract}

Kata kunci: adsorben, aplikasi, daun jati kering, metilen biru, preparasi, sistem batch

\section{PREPARATION OF FALLEN TEAK LEAF (Tectona grandis) POWDER FOR BATCH STUDY OF METHYLENE BLUE ADSORPTION}

\author{
Dwi Ima Hikmawati ${ }^{1}$ \\ Program Studi Teknik Kimia, Fakultas Teknik, Universitas PGRI Madiun ${ }^{1}$ \\ ${ }^{1)}$ Email: di.hikmawati@unipma,ac,id
}

\begin{abstract}
The development of adsorbents to overcome environmental problems is a continuous innovation have still done by researchers. In this study, fallen teak leaf (Tectona grandis) was successfully prepared as adsorbent for methylene blue dissolved in water. Teak leaf deciduous was prepared into powder and washed using tap water and aquadest until colorless filtrate was obtained. Drying of teak leaves powder has been done at $67^{\circ} \mathrm{C}$ for 12 hours. The adsorption process is studied through a batch system without temperature measurement and change $\mathrm{pH}$ value. The materials characteristic of adsorption were studied through a batch system at ambient temperature and $\mathrm{pH}$. The operational parameters given for evaluating adsorbent performance were contact time, adsorbent mass: $M B$ volume ratio, and initial MB concentration. Adsorption process used a magnetic stirrer with agitation speed of $800 \mathrm{rpm}$. The adsorption percentage of $M B$ was $98.56 \%$ by adsorbent mass: the volume ratio of $1 \mathrm{~g}$ : $35 \mathrm{~mL}$ for 30 minutes of contact time. This study showed that the dried teak leaves have good potential and need to be explored as low cost and effective adsorbents.
\end{abstract}

Keyword:adsorbent, application, dry teak leaf, methylene blue, preparation, batch system 


\section{PENDAHULUAN}

Air merupakan kebutuhan penting untuk semua bentuk kehidupan di bumi. Lebih dari $70 \%$ permukaan bumi tertutup oleh air, namun sebagian besar kurang cocok untuk kehidupan manusia. Pemakaian bahan kimia yang luas dalam kegiatan industri dan rumah tangga menyebabkan kontaminasi iar permukaan yang tidak diinginkan. Saat ini, perhatian terhadap tatanan keseimbangan lingkungan telah meningkat, terutama mengenai dampak buruk bahan pencemar dalam limbah yang mencemari lingkungan termasuk zat warna (Sartla Yadav, 2012). Dari berbagai jenis zat warna, senyawa azo lebih sering digunakan lebih dari setengah produksi pewarna. Sekitar $2 \%$ dari zat warna yang dihasilkan setiap tahun, terbuang sebagai limbah dengan proses manufaktur yang beragam. Di sisi lain, diperkirakan sekitar 10-15\% zat warna dari industri tekstil berada dalam limbah cair yang terbuang ke lingkungan setiap tahunnya (Bari \& Bhardwaj, 2014). Kontaminasi air limbah oleh zat warna mudah dikenali, terutama untuk limbah dengan intensitas pewarnaan yang kuat dan stabilitasnya yang tinggi terhadap cahaya, suhu, air, bahan kimia, dan aktivitas mikroba. Hal ini juga mengakibatkan meningkatnya nilai BOD dan COD (Kumar et al., 2011), nilai pH yang berubah-ubah, dan merusak estetika perairan. Oleh karena itu, pengurangan konsentrasi zat pewarna merupakan aspek yang perlu dilakukan untuk perlakuan awal sebelum limbah cair dibuang ke lingkungan.

Adsorpsi merupakan metode yang sangat populer dan sering digunakan. Pada proses ini, adsorben memiliki peran utama, sehingga efektifitas adsorpsi tergantung pada sifat dan kinerja adsorben. Sebelumnya, adsorben yang paling sering digunakan dalam proses adsorpsi adalah karbon aktif tetapi karbon aktif yang memiliki kualitas bagus biasanya lebih mahal karena biaya produksinya yang lebih tinggi. Di samping itu, regenerasi karbon aktif dengan larutan dapat menghasilkan adanya tambahan pengotor, sedangkan regenerasi dengan teknik refraktori menyebabkan pengurangan jumlah adsorben sebesar 10-15\% (Gupta \& Suhas, 2009; Salleh et al., 2011). Seiring berkembangnya penelitian, biomassa dilaporkan mampu meminimalisir polutan yang terkandung dalam limbah cair. Peristiwa ini merupakan pendekatan baru dan dianggap lebih menguntungkan karena tidak memerlukan biaya produksi yang tinggi, desain sederhana, ketersediaan melimpah, dan kinerja yang efektif (Boukhlifi et al., 20013).

Daun jati merupakan salah satu jenis biomassa yang melimpah di kawasan Madiun. Selama ini, daun jati yang gugur dibiarkan di permukaan tanah atau dibakar oleh pemiliknya. Seperti biomassa yang lain, daun jati diperkirakan memiliki kemampuan dalam mengadsorpsi zat warna. Beberapa penelitian tentang pemanfaatan daun jati sebagai adsorben pernah dilakukan tetapi masih sangat jarang. King et al. (2006) melaporkan aktivitas serbuk daun jati sebagai adsorben untuk logam berat $\mathrm{Cu}$ (II). Hasil penelitian menunjukkan bahwa material mampu mengadsorp 71,66\% Cu (II) dari $30 \mathrm{~mL}$ larutan uji 20 ppm dalam waktu 180 menit dengan metode batch. Jadhav \& Bamane (2016) melaporkan serbuk daun jati sebagai adsorben ion Cr (VI) dari larutan. Sebelumnya, Rathnakumar et. al. (2009) melakukan studi kinetika dan termodinamika serbuk daun jati untuk pengurangan kadar $\mathrm{Cu}$ (II) dari larutan. Vilvanathan 
\& Shanthakumar (2014) juga menggunakan serbuk daun jati untuk adsorpsi ion logam $\mathrm{Ni}(\mathrm{II})$ dan $\mathrm{Co}$ (II) dengan efisiensi pengurangan terhadap ion $\mathrm{Ni}$ (II) dan $\mathrm{Co}$ (II) berturut-turut sebesar 75,64 dan 76,04\% .

Penggunaan daun jati sebagai adsorben zat warna juga pernah dilakukan. Oyelude et al. (2017) melaporkan kemampuan sampah daun jati untuk adsorpsi zat warna eosyn yellow dari larutan. Hasinya menunjukkan aktivitas sampah daun jati masih rendah dan perlu untuk ditingkatkan. Efisiensi adsorpsi sebesar 74,88\% dicapai dengan jumlah adsorben $12 \mathrm{~g} / \mathrm{L}$. Oleh karena itu, perlu dilakukan penelitian lebih lanjut untuk meningkatkan aktivitas adsorpsi daun jati. Efektivitas pengurangan zat warna dalam limbah oleh masing-masing biomassa yang diberikan dipengaruhi beberapa parameter operasional misalnya luas permukaan adsorben, kemampuan alamiah biomassa, $\mathrm{pH}$ larutan, jenis pewarna, dan konsentrasi zat pewarna. Dalam penelitian ini, serbuk daun jati akan diuji kemampuannya terhadap metilen biru (MB) dalam larutan dengan beberapa variasi parameter operasional adsorpsi dengan sistem batch.

\section{MATERIAL DAN METODE}

Daun jati kering dikumpulkan dari kebun di pekarangan rumah warga di desa Sirapan, Madiun, Jawa Timur. Daun jati kering terkumpul dicuci dengan air kran untuk membersihkan kotoran yang menempel dipermukaannya. Lalu daun jati dikeringkan di bawah terik matahari hingga kering. Setelah itu, daun jati diremas menjadi bagian yang lebih kecil dan dipisahkan dari tulang daunnya, lalu dihaluskan.

Sebanyak 100 gram serbuk daun jati dicuci dengan $150 \mathrm{~mL}$ air kran, dilanjutkan dengan $150 \mathrm{~mL}$ aquades masing-masing selama 12 jam sebanyak tiga kali dan setiap pergantian pelarut dikeringkan pada suhu $67^{\circ} \mathrm{C}$ sampai kering. Larutan induk metilen biru (MB) 1000 ppm untuk kurva kalibrasi zat warna dibuat dengan melarutkan 0,1 gram MB dalam $100 \mathrm{~mL}$ aquades.

Percobaan dikerjakan dengan sistem batch dalam botol kaca $150 \mathrm{~mL}$ menggunakan $50 \mathrm{~mL}$ larutan pada suhu ambien di atas hot plate stirrer dan kecepatan pengadukan sebesar $800 \mathrm{rpm}$. Variasi parameter operasi yang dilakukan dalam percabaan ditabulasikan pada Tabel 1.

Tabel 1. Variasi Parameter Operasi dalam Eksperimen

\section{Tujuan Eksperimen \\ Parameter Operasi}

\begin{tabular}{cc}
\hline Mempelajari pengaruh & $25 \mathrm{~mL}$ larutan MB; suhu ambien; massa ads. 1 g; waktu kontak \\
waktu kontak & $10,15,20,25$, dan 30 menit; konsentrasi awal MB $50 \mathrm{ppm}$ \\
mempelajari pengaruh & $25 \mathrm{~mL}$ larutan MB; suhu ambien; massa ads. 1 g; waktu kontak \\
variasi konsentrasi awal & $10,15,20,25$, dan 30 menit; konsentrasi awal 25 ppm dan $50 \mathrm{ppm}$ \\
mempelajari pengaruh & waktu kontak $10,15,20,25$, dan 30 menit, suhu ambien; rasio \\
variasi rasio massa & massa: volume $0,5: 25 ; 1: 25 ;$ dan $1: 35$ \\
adsorben: volume larutan &
\end{tabular}

Kurva kalibrasi diukur menggunakan larutan MB dengan variasi konsentrasi 0-5 ppm. Filtrat MB

setelah adsorpsi dianalisis menggunakan spektrofotometer single beam UV/Vis pada panjang 
gelombang $664 \mathrm{~nm}$. Persentase pengurangan MB dan kapasitas adsorpsi MB dihitung berdasarkan persamaan 1 dan 2 .

$$
\% \text { pengurangan } M B=\frac{C_{i}-C_{f}}{C_{i}} \times 100
$$

Di mana $C_{i}$ adalah konsentrasi MB awal, dan $C_{f}$ adalah konsentrasi MB akhir.

$$
q_{e}=\frac{\left(C_{i}-C_{f}\right) V}{W}
$$

Dengan $q_{e}$ adalah jumlah MB yang diadsorpsi (mg/g), W massa adsorben (g), V adalah volume larutan (L), $C_{i}$ adalah konsentrasi awal larutan $\mathrm{MB}$, dan $C_{f}$ adalah konsentrasi akhir larutan $\mathrm{MB}$.

\section{HASIL DAN PEMBAHASAN}

\subsection{Preparasi Adsorben}

Pemanfaatan material yang tersedia di alam yang melimpah sebagai adsorben yang ramah lingkungan untuk menggantikan adsorben konvensional dan mahal berdasarkan sudut pandang ekonomi dan lingkungan kini telah menjadi perhatian yang menarik sejumlah peneliti. Jati merupakan tanaman yang banyak tumbuh di Madiun. Penelitian ini memanfaatkan daun jati tua yang gugur yang gugur dari pohon. Preparasi guguran daun jati kering diawali dengan pencucian menggunakan air kran untuk membersihkan kotoran yang menempel dipermukaannya. Setelah itu, daun jati bersih dikeringkan di bawah terik matahari hingga kering untuk menghilangkan sisa air. Setelah itu, daun jati diremas menjadi bagian yang lebih kecil dan dipisahkan dari tulang daunnya. Proses pembuatan serbuk daun jati dikerjakan dengan blender lokal.

Sebanyak 100 gram serbuk daun jati dicuci dengan $150 \mathrm{~mL}$ air kran sebanyak tiga kali, dilanjutkan dengan $150 \mathrm{~mL}$ aquades masing-masing selama 12 jam sebanyak tiga kali hingga diperoleh filtrat yang tidak berwarna. Terakhir serbuk daun jati dikeringkan pada suhu $67^{\circ} \mathrm{C}$ sampai kering setiap kali pergantian pelarut. Serbuk daun jati yang sudah kering disimpan di botol tertutup untuk menghindari penyerapan air dan siap untuk digunakan. Penampakan adsorben daun jati disajikan pada Gambar 1.

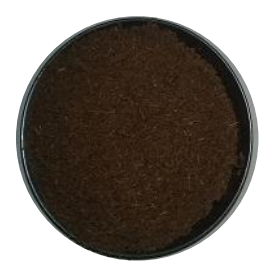

Gambar 1. Adsorben Daun Jati (Tectona grandis)

\subsection{Studi Adsorpsi Metilen Biru}

Dalam penelitian ini metilen biru (MB) dipilih sebagai model untuk mengevaluasi kemampuan adsorben yang telah dibuat. MB merupakan zat warna kationik dengan rumus molekul $\mathrm{C}_{16} \mathrm{H}_{18} \mathrm{ClN}_{3} \mathrm{~S} .3 \mathrm{H}_{2} \mathrm{O}$. MB dipilih karena memiliki kemampuan untuk terikat pada padatan dengan baik.

Proses adsorpsi MB dikerjakan sesuai dengan variasi parameter operasi yang disajikan pada Tabel 1. Proses adsorpsi dengan sistem batch dilakukan di atas hot plate magnetic stirrer dengan kecepatan 
$700 \mathrm{rpm}$, tanpa pengubahan $\mathrm{pH}$ dan suhu, dimana $\mathrm{pH}$ dan suhu terukur berturut-urut 5,5 dan $30{ }^{\circ} \mathrm{C}$ untuk semua variasi.Konsentrasi MB yang tersisa pada filtrat dipisahkan menggunakan centrifuge kemudian diukur absorbansinya dengan Spektrofotometri UV-Vis pada panjang gelombang $664 \mathrm{~nm}$, yang merupakan panjang gelombang optimum untuk MB. Adsorpsi metilen biru dari larutan dipelajari sebagai fungsi dari waktu kontak, konsentrasi awal larutan MB, dan rasio massa adsorben:volume larutan MB.

\subsubsection{Pengaruh Variasi Rasio Massa Adsorben dan Volume Larutan Metilen Biru}

Waktu kontak merupakan parameter penting untuk menentukan kondisi di mana proses adsorpsi mencapai keadaan setimbang. Variasi waktu diujikan untuk mengetahui seberapa lama proses adsorpsi yang diperlukan untuk mendapatkan penyerapan zat warna terbesar. Waktu adsorpsi yang divariasikan adalah 10, 15, 20, 25, dan 30 menit.

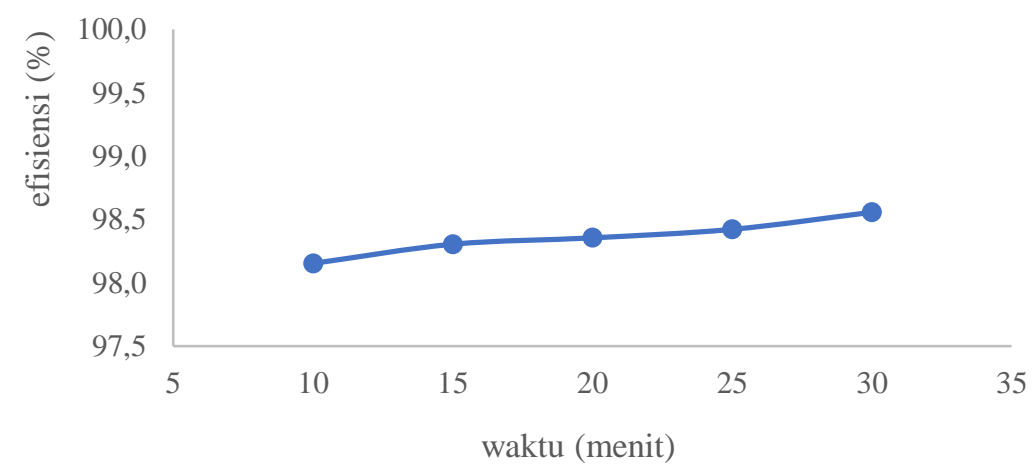

Gambar 3. Pengaruh Variasi Waktu terhadap Efisiensi Adsorpsi MB oleh Adsorben

Profil pengaruh waktu kontak terhadap adsorpsi larutan metilen biru dari $50 \mathrm{mg} / \mathrm{L}$ larutan MB ditunjukkan pada Gambar 3. Data yang diperoleh dari proses adsorpsi larutan MB pada permukaan adsorben daun jati menunjukkan bahwa efisiensi pengurangan MB meningkat seiring dengan meningkatnya waktu kontak. Hal ini disebabkan semakin lama waktu kontak pemukaan adsorben dengan larutan $\mathrm{MB}$, kemungkinan molekul MB yang berinteraksi dengan permukaan padatan semakin besar. sehingga, metilen biru yang tersisa dalam larutan semakin berkurang. Pengurangan terbesar dalam rentang waktu yang diberikan pada proses adsorpsi adalah pada waktu kontak 30 menit. Efisiensi adsorpsi daun jati terhadap $50 \mathrm{mg} / \mathrm{L}$ larutan MB sebesar 98,56\%.

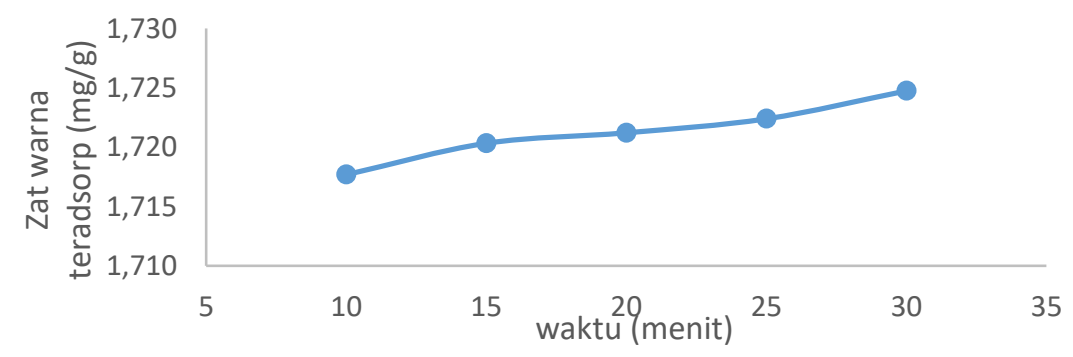


Kapasitas adsorpsi dihitung dengan tujuan untuk mengetahui kemampuan penyerapan MB oleh adsorben daun jati. Berdasarkan Gambar 4, kapasitas adsorpsi tertinggi dicapai pada waktu kontak 30 menit, yakni sebesar $1,725 \mathrm{mg} / \mathrm{g}$, sedangkan terendahnya dicapai pada waktu kontak 10 menit, yaitu sebesar $1,718 \mathrm{mg} / \mathrm{g}$.

\subsubsection{Pengaruh Konsentrasi Awal Larutan MB}

Studi pengaruh konsentrasi awal pada pengurangan MB oleh adsorben daun jati dari larutan dipelajari dengan 2 variasi konsentrasi awal 25 dan $50 \mathrm{mg} / \mathrm{L}$. Pengaruh konsentrasi MB awal ini diamati sebagai fungsi dari waktu kontak. Hasil yang diperoleh disajikan pada Gambar 5. Data tersebut menunjukkan bahwa pada konsentrasi $25 \mathrm{mg} / \mathrm{L}$ profil pengurangan konsentrasi larutan MB berkurang perlahan pada waktu kontak 15 menit dan meningkat dengan cepat pada menit ke 20, lalu berkurang lambat pada menit selanjutnya. Sedangkan pada konsentrasi MB 50 ppm, pengurangan MB meningkat pada menit ke 15 , kemudian turun dengan cepat pada menit ke 20, dan berturut-turut meningkat dan berkurang kembali pada menit selanjutnya.

Efisiensi adsorpsi terbesar yang dicapai oleh adsorben daun jati pada kedua variasi konsentrasi MB adalah sama, yaitu sebesar 98,12\%. Yang mana efisiensi tersebut dicapai pada waktu kontak 15 dan 20 menit berturut-turut untuk konsentrasi awal MB 50 dan $25 \mathrm{mg} / \mathrm{L}$. Berdasarkan hasil tersebut, diduga keadaan setimbang pada adsorpsi MB dengan konsentrasi awal $25 \mathrm{mg} / \mathrm{L}$ dan $50 \mathrm{mg} / \mathrm{L}$ masingmasing dicapai pada menit ke 20 dan ke 15 .

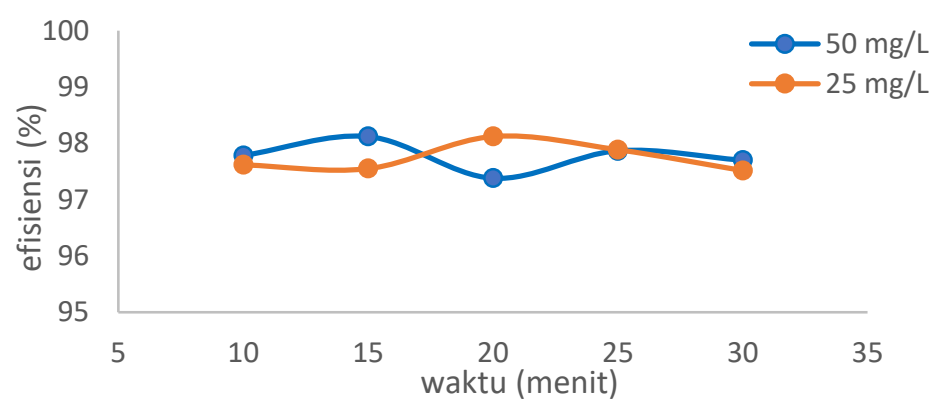

Gambar 5. Pengaruh Konsentrasi Awal terhadap Efisiensi Adsorpsi MB oleh Adsorben

Variasi konsentrasi awal larutan metilen biru berkaitan erat dengan harga kapasitas adsorpsi adsorben. Kapasitas adsorpsi pada variasi konsentrasi MB awal disajikan pada Gambar 6. Berdasarkan Gambar tersebut, kapasitas adsorpsi dengan konsentrasi awal $50 \mathrm{mg} / \mathrm{L}$ pada semua variasi waktu kontak lebih tinggi daripada kapasitas adsorpsi dengan konsentrasi awal $25 \mathrm{mg} / \mathrm{L}$. Hal ini menunjukkan bahwa, semakin besar konsentrasi kapasitas adsorpsinya meningkat, meskipun efisiensi adsorpsinya sama. Pada konsentrasi awal MB sebesar $25 \mathrm{mg} / \mathrm{L}$, kapasitas adsorpsi kapasitas adsorpsi tertinggi dicapai pada waktu kontak 20 menit, yakni sebesar $0,613 \mathrm{mg} / \mathrm{g}$, sedangkan terendahnya dicapai pada waktu kontak 
30 menit, yaitu sebesar 0,609 mg/g. Pada konsentrasi awal MB sebesar $50 \mathrm{mg} / \mathrm{L}$, kapasitas adsorpsi kapasitas adsorpsi tertinggi dicapai pada waktu kontak 15 menit, yakni sebesar 1,226 mg/g, sedangkan terendahnya dicapai pada waktu kontak 20 menit, yaitu $1,217 \mathrm{mg} / \mathrm{g}$.

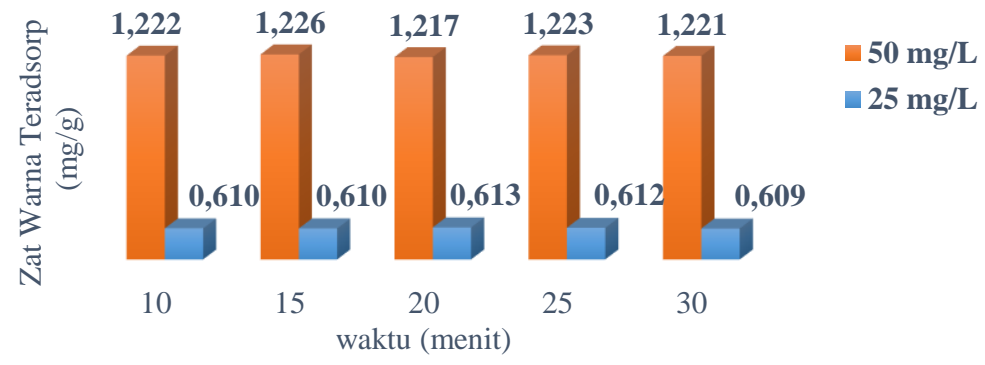

Gambar 6. Pengaruh Konsentrasi Awal terhadap Kapasitas Adsorpsi MB oleh Adsorben

\subsubsection{Pengaruh Variasi Rasio Massa Adsorben dan Volume Larutan Metilen Biru}

Pengaruh variasi rasio massa adsorben dan volume larutan metilen biru dievaluasi dengan 3 variasi, yaitu $1 \mathrm{~g}: 35 \mathrm{~mL} ; 1 \mathrm{~g}: 25 \mathrm{~mL}$; dan 0,5:25 mL. Rasio adsorben terhadap pelarut mempengaruhi seberapa besar kapasitas adsorpsi MB yang terserap oleh daun jati. Variasi rasio massa adsorben dan volume larutan metilen biru ini dipelajari sebagai fungsi terhadap waktu kontak. Masing-masing variasi diujikan pada waktu kontak 10, 15, 20, 25, dan 30 menit. Gambar 7 menyajikan profil data percobaan dengan variasi rasio massa adsorben terhadap volume larutan metilen biru.

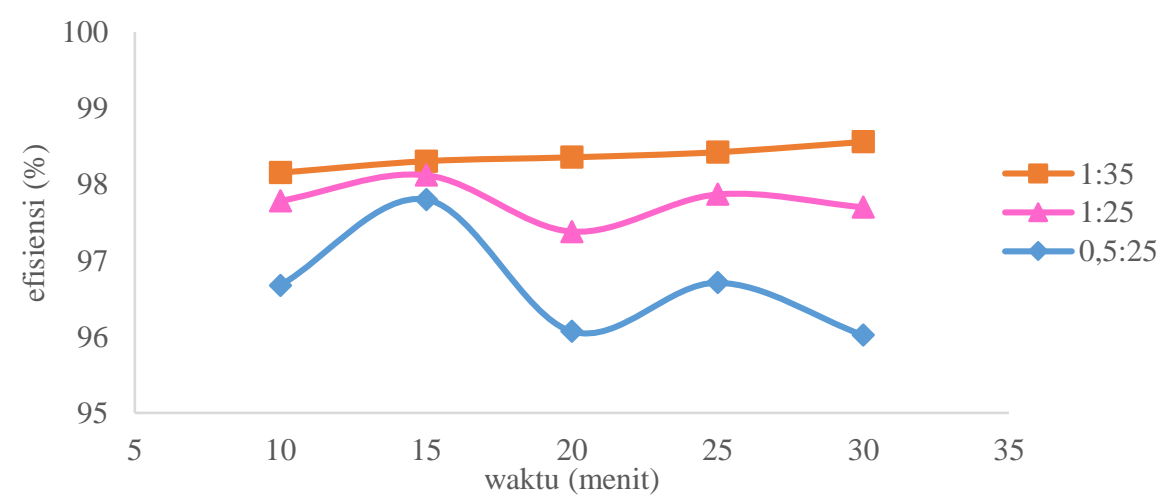

Gambar 7. Pengaruh Rasio Massa Adsorben:Volume Larutan terhadap Efisiensi Adsorpsi MB

Pada rasio 1:35 efisiensi adsorpsi MB meningkat seiring dengan meningkatya waktu kontak. Pola yang berbeda ditunjukkan oleh rasio 1:25 dan 0,5:25. Pada kedua variasi tersebut, efisiensi adsorpsi meningkat dari menit ke 10 hingga menit ke 15, berkurang pada menit ke 20, meningkat kembali pada menit ke 25 dan berkurang pada menit ke 30. Efisiensi tertinggi pada rasio 1:25 sebesar 98,12\%, sedangkan rasio 0,5:25 menunjukkan efisiensi sebesar 97,80\%. Hasil tersebut mengindikasikan bahwa efisiensi adsorpsi meningkat seiring dengan meningkatnya rasio massa adsorben terhadap volume larutan MB. Dengan kata lain, semakin banyak jumlah adsorben yang diaplikasikan pada volume 
larutan yang sama efisiensi adsorpsinya semakin besar.

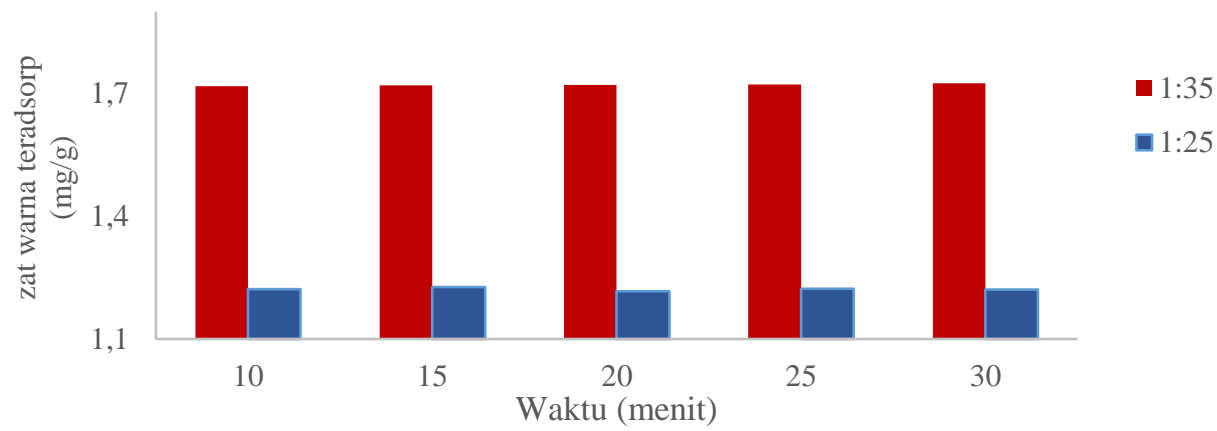

Gambar 8. Pengaruh Rasio Massa Adsorben:Volume Larutan terhadap Kapasitas Adsorpsi MB

Pengaruh rasio massa adsorben:volume larutan metilen biru terhadap kapasitas adsorpsi disajikan pada Gambar 8. Berdasarkan Gambar tersebut, kapasitas adsorpsi berkurang dengan semakin besarnya rasio massa adsorben:volume larutan metilen biru akibat penambahan volume larutan. Hal ini ditunjukkan dari data yang diperoleh pada variasi rasio 1:35 dan 1:25. Kapasitas adsorpsi terbesar pada kedua variasi dicapai pada rasio 1:35, yakni 1,725 mg/g dengan waktu kontak 30 menit.

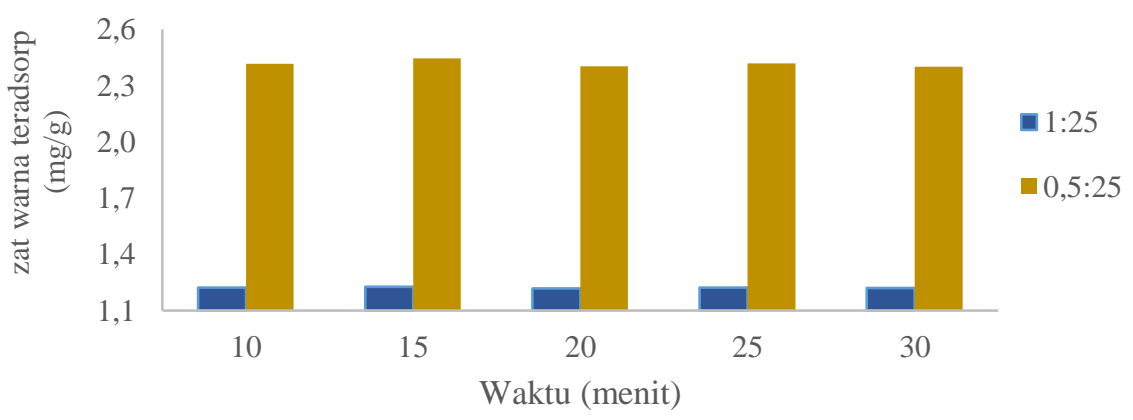

Gambar 9. Pengaruh Rasio Massa Adsorben:Volume Larutan terhadap Kapasitas Adsorpsi MB

Gambar 9 menggambarkan pengaruh variasi rasio massa adsorben:volume larutan MB akibat penambahan massa. Berdasarkan data variasi rasio 1:25 dan 0,5:25 diketahui bahwa kapasitas adsorpsi meningkat dengan berkurangnya massa adsorben. Kapasitas adsorpsi tertinggi pada kedua variasi ini dicapai pada 0,5:25, yaitu sebesar 2,445 mg/g dengan waktu kontak 15 menit.

\section{KESIMPULAN DAN SARAN}

Berdasarkan hasil penelitian ini, kesimpulan yang diperoleh adalah:

1. Semakin besar waktu kontak, kapasitas adsorpsi adsorben daun jati semakin besar. kapasitas adsorpsi terbesar diperoleh pada waktu kontak 30 menit sebesar 1,725 mg/g dengan efisiensi adsorpsi mencapai $98,56 \%$.

2. Semakin besar konsentrasi awal larutan MB, kapasitas adsorpsinya meningkat. Kapasitas adsorpsi tertinggi dicapai pada waktu kontak 20 menit, yakni sebesar 0,613 mg/g, sedangkan terendahnya pada konsentrasi awal MB sebesar $25 \mathrm{mg} / \mathrm{L}$ dicapai pada waktu kontak 30 menit, yaitu sebesar 
0,609 mg/g, sedangkan pada konsentrasi awal MB sebesar $50 \mathrm{mg} / \mathrm{L}$ dicapai pada waktu kontak 15 menit, yakni sebesar $1,226 \mathrm{mg} / \mathrm{g}$.

3. Kapasitas adsorpsi meningkat dengan bertambahnya volume Larutan MB. Hal ini ditunjukkan dari data yang diperoleh pada variasi rasio 1:35 dan 1:25. Kapasitas adsorpsi terbesar pada kedua variasi dicapai pada rasio 1:35, yakni 1,725 mg/g dengan waktu kontak 30 menit.

4. Kapasitas adsorpsi meningkat dengan berkurangnya massa adsorben. Kapasitas adsorpsi tertinggi pada kedua variasi rasio 1:25 dan 0,5:25 dicapai pada 0,5:25, yaitu sebesar 2,445 mg/g dengan waktu kontak 15 menit.

\section{UCAPAN TERIMA KASIH}

Penulis mengucapkan terima kasih kepada LPPM Universitas PGRI Madiun yang telah telah memberikan dana penelitian. Penulis juga menyampaikan terima kasih kepada Program Studi Teknik Kimia, Program Studi Pendidikan Biologi, Kepala Laboratorium Biologi Universitas PGRI Madiun, Fakultas Ilmu Alam Institut Teknologi Sepuluh November, rekan-rekan Dosen Program Teknik Kimia UNIPMA dan pihak lain yang telah memberikan dukungan sehingga penelitian ini dapat terlaksana.

\section{DAFTAR PUSTAKA}

Bari, Q. \& Bhardwaj, N. 2014. Role of Bio-sorbents in the Decolorization of Some Commonly Used Dyes. Journal of science, 4 (10): 637-642.

Boukhlifi F, Chraibi S and Alami M. 2013. Evaluation of the Adsorption Kinetics and Equilibrium for the Potential Removal of Phenol Using a New Biosorbent, J. Environ. Earth Sci, 3: 181-191.

Gupta, V .K. and Suhas. 2009. Application of Low-Cost Adsorbents for Dye Removal-A Review. Journal Environment Management. 90: 2313-2342.

King, P., Srinivas, P., Kumar, Y.P., Prasad, V.S.R.K. 2006. Sorption of copper (II) ion from aqueous solution by Tectona grandis 1.f. (teak leaves powder). Journal of Hazardous Materials, B136: (2006) 560-566.

Kumar, P.S., S. Ramalingam, and K. Sathish. 2011. Removal of Methylene Blue Dye from Aqueous Solution by Activated Carbon Prepared from Cashew Nut Shell as a New Low-Cost Adsorbent. Korean Journal of Chemical Engineering. 28: 149-155.

Oyelude, E.O., Awudza, J.A.M., Twumasi, S.K. 2017. Equilibrium, Kinetic and Thermodynamic Study of Removal of Eosin Yellow from Aqueous Solution Using Teak Leaf Litter Powder. Scientific Reports, 7: 1-10.

Rathnakumar, S., Sheeja, R.Y., \& Murugesan, T. 2009. Removal of Copper (II) from Aqueous Solutions Using Teak (Tectona grandis L.f) Leaves. World Academy of Science, Engineering and Technology, 56: 880-884. 
Salleh, M.A.M., D.K. Mahmoud, W.A. Karim, and A. Idris. 2011. Cationic and Anionic Dye Adsorption by Agricultural Solid Wastes: a Comprehensive. Review Desalination. 280: 113.

Vilvanathan S, \& Shanthakumar, S. 2016. Removal of $\mathrm{Ni}(\mathrm{II})$ and $\mathrm{Co}(\mathrm{II})$ ions from aqueous solution using teak (Tectona grandis) leaves powder: adsorption kinetics, equilibrium and thermodynamics study, Desalination and Water Treatment, 57: 3995-4007. 